\title{
Toxicity of Organic and Inorganic Nickel in Pancreatic Cell Cultures: Comparison to Cadmium
}

\author{
David R Wallace*1, Aleksandra Buha-Djordjevic ${ }^{2}$, Alexander Benton ${ }^{3}$ \\ ${ }^{1}$ Oklahoma State University Center for Health Sciences, School of Biomedical Sciences \\ and Interdisciplinary Toxicology Program, 1111 West $17^{\text {th }}$ Street, Tulsa Oklahoma, \\ 74107-1898 United States \\ ${ }^{2}$ University of Belgrade - Faculty of Pharmacy, Department of Toxicology “Akademik \\ Danilo Soldatović", Vojvode Stepe 450, 11221 Belgrade, Serbia \\ ${ }^{3}$ Oklahoma State University, Department of Biochemistry and Molecular Biology, \\ Program in Biochemistry and Molecular Biology, Noble Research Center, Stillwater, \\ Oklahoma, 74078 United States
}

*Corresponding Author: David R Wallace, E-mail: david.wallace@okstate.edu

\begin{abstract}
Nickel compounds are Group 1 carcinogens and possibly cancer-causing in the pancreas. We examined the toxicity of nickel in both 2-D and 3-D pancreatic cell cultures, to determine the $\mathrm{LD}_{50}$ for organic and inorganic nickel in normal and cancerous cells. Assays with cadmium chloride were performed to be a comparison to potential nickel-induced toxicity. Cells were exposed to twelve concentrations of $\mathrm{NiCl}_{2}$ or $\mathrm{Ni}-(\mathrm{Ac})_{2}$ for $48 \mathrm{~h}(2-\mathrm{D})$, or six concentrations for 48 hours (3-D). There was a significant $(\mathrm{P}=0.0016)$ difference between HPNE and AsPC-1 $\mathrm{LD}_{50}$ values after cadmium exposure, at $69.9 \mu \mathrm{M}$ and $29.2 \mu \mathrm{M}$, respectively. Neither form of nickel exhibited toxicity in 2-D or 3-D cultures, but after $48 \mathrm{~h}$, changes in spheroid morphology were observed. The inability of $\mathrm{Ni}$ to reduce viable cell numbers suggests a toxic mechanism that differs from cadmium, also a Group 1 carcinogen. The cell microenvironment was not a factor in nickel toxicity with no changes in viable cells in either 2-D or 3-D cultures. These studies only examined cytotoxicity, and not genotoxicity, a potential mechanism of nickel carcinogenicity. Alterations in DNA function or the expression of apoptotic proteins/processes would take longer to manifest. Current work focuses on cellular changes following extended nickel exposure.
\end{abstract}

Key Words: nickel; cadmium; cytotoxicity; toxic metals; cancer

DOI: https://doi.org/10.5937/arhfarm70-29277 


\section{Introduction}

Nickel (Ni) is a ubiquitous metal found naturally in the environment and associated with manufacturing and commercial processes (1). Our understanding of Ni-related toxicity has linked Ni exposure to multiple disease states $(2,3)$. Exposure to Ni may also occur by consumption of contaminated foods or agricultural products $(4,5)$. Besides contaminating sources such as commercial items, a major source of $\mathrm{Ni}$ is through vaping and the inhalation of $\mathrm{Ni}$ contaminated vapor $(6,7)$. Numerous reports have linked exposure to Ni through processes like welding, electroplating, and painting (8-11). Of the metals that fall within the broad category of 'heavy metals,' Ni has been understudied compared to metals like mercury, lead, cadmium $(\mathrm{Cd})$, and manganese. $\mathrm{Cd}$ and $\mathrm{Ni}$ are often found together in the environment. Both metals have been shown to bind to soil humic substances, which facilitates the joint movement of the metals through the environment (12). Ni has presented an insidious health risk with symptoms not presenting for months/years after exposure. It has been shown that $\mathrm{Ni}$ accumulates in different organ systems at different rates. The lungs and thyroid are areas rich $(140-170 \mu \mathrm{g} / \mathrm{kg})$ in Ni, whereas the pancreas has one of the lowest Ni content at $34 \mu \mathrm{g} / \mathrm{kg}$ (range of 7-71 $\mu \mathrm{g} / \mathrm{kg}$ ) in humans (13). Ni is not readily cleared from the body and may bioaccumulate, posing additional health risks. Recent evidence suggests that $\mathrm{Ni}$ exposure may result in endocrine-related changes, including tumor formation (14-16). Similar to Cd, Ni has been suspected of acting as a metalloestrogen, activating the estrogen ER $\alpha$ receptor, but overall, the information is scarce (17). A critical action of Ni-mediated toxicity has been reported to be the generation of free radicals and the promotion of oxidative stress (1820), leading to an increase in lipid peroxidation (21).

Pancreatic cancer (PC) is one of the most lethal human cancers and an important cause of cancer-associated-mortalities worldwide $(22,23)$. The primary environmental factors associated with PC so far are inhalation of cigarette smoke, exposure to mutagenic nitrosamines, chlorinated hydrocarbon solvents, and heavy metals (24). Involuntary exposure to heavy metals in humans, particular attention to $\mathrm{Cd}$, is important due to its abundance as an occupational and environmental pollutant (25). Previous studies have linked Cd exposure and PC development due to $\mathrm{Cd}$ accumulation in the pancreas $(26,27)$. We chose to use $\mathrm{Cd}$ as a form of internal control based on its known ability to cause cell death and promote pancreatic cancer pathogenesis. Global health organizations have listed both $\mathrm{Cd}$ and $\mathrm{Ni}$ as class I carcinogens $(28,29)$. Reviews from different groups have outlined the mechanisms associated with metal- and metalloid-induced toxicity leading to cancer development $(16,29,30)$. A positive correlation between Cd concentration and the incidence of PC has been reported for samples taken from toenails (31). However, there was a negative correlation between Ni concentration and PC incidence (31). A similar negative correlation for $\mathrm{Ni}$ concentration in the pancreas has been reported in early pancreatitis (32). In cases of PC, Ni is present in pancreatic juices but does not directly 
correlate with cancer incidence; instead elevated $\mathrm{Ni}$ content correlates with elevated chromium in the pancreatic juice $(28,33)$. This secondary correlation suggests an indirect involvement of Ni.

Historically available technology limited cell culture work. Work in two dimensions (2-D) predominates the literature. Recently, technology has permitted the development of cell culture work in three dimensions (3-D). Multiple platforms exist for developing 3-D cultures, including the use of specialized 96-well plates with concave wells, which is our model system (34-36). The technologies available are outlined in numerous reviews, and these authors stress the importance of the 3-D model in capturing the complexity associated with the naturally occurring tumor environment (37-40). Since 3-D methodologies are relatively new, most of the literature published is over the last five years. Literature describing the use of 3-D culture for the study of PC is scarce. There have been no reports describing HPNE cells in 3-D culture, and publications describing the AsPC-1 cells in culture are few $(34,41,42)$. This lack of information is one of the foundations for the importance of the studies presented here.

To best determine toxicity following metal exposure, the appropriate cell microenvironment was utilized. There are limitations with the conventional 2-D culture methods, with 3-D cultures being touted as a good alternative to 2-D culture models. We aim is to develop and use assay conditions that further our understanding of PC biology in 3-D cultures and establish criteria for studying toxic mixtures of environmental toxicants. The goal of these studies is to compare the effects of nickel chloride $\left(\mathrm{NiCl}_{2}\right)$ or nickel acetate $\left(\mathrm{Ni}-(\mathrm{Ac})_{2}\right)$ on the viability of HPNE and AsPC-1 pancreatic cells. Two growth methodologies are utilized (2-D v. 3-D) to examine the effects of cell microenvironment on the cellular response to $\mathrm{NiCl}_{2}$ exposure.

Collectively, these studies are the first to compare the development and functionality of spheroids for the HPNE and AsPC-1 cell lines and examine Ni-mediated toxicity in both 2-D and 3-D cultures. As the current methodology improves, the use of spheroids to accurately mimic the milieu of the tumor will be vital.

\section{Methods}

Cell Lines and Cell Culture Maintenance: Cell lines were obtained from American Type Culture Collection (ATCC, Manassas, VA). Pancreas hTERT-HPNE ("Human Pancreatic Nestin-Expressing"; ATCC ${ }^{\circledR}$ CRL-4023 ${ }^{\mathrm{TM}}$, immortalized control pancreatic cells - referred to as 'HPNE') and AsPC-1 (ATCC ${ }^{\circledR}$ CRL-1682 ${ }^{\mathrm{TM}}$, pancreatic tumor cells) were grown and maintained, as described in ATCC protocols. Cells were maintained at $37^{\circ} \mathrm{C}$ with $5 \% \mathrm{CO}_{2}$. hTERT-HPNE cell line is a control human pancreatic ductal cells that were transfected with the hTERT gene using the retroviral expression vector, pBABEpuro. Transfected cells did not senesce and continued to proliferate (43). 
Cell Treatment: Cells were initially grown in a $25 \mathrm{~cm}^{2}$ flask to near confluence having reached their exponential growth phase. Cells were then trypsinized, removed, and subjected to Trypan Blue cell counting using a Corning ${ }^{\circledR}$ CytoSMART cell counter. Cells were diluted in growth media to a final concentration of $10^{5}$ cells $/ \mathrm{mL}$ before the addition of $100 \mu \mathrm{L}$ of cell suspension per well. Cells were returned to the incubator for $24 \mathrm{~h}$, after which the media was removed, and assay media (MEM with 1\% FBS; no phenol) was added with the appropriate concentration of $\mathrm{NiCl}_{2}$ or $\mathrm{Ni}-(\mathrm{Ac})_{2}$ and the exposure to $\mathrm{Ni}$ was continued for $48 \mathrm{~h}$.

3-D Spheroid Culture Growth: Cells were maintained using conventional methods and grown in a $25 \mathrm{~cm}^{2}$ flask (approximately $80 \%$ confluent; the exponential part of the growth phase). Cells were trypsinized for removal from the flask, and media was added to yield a final concentration of approximately $2.5 \times 10^{4}$ cells/well. To promote orderly spheroid growth, clumps of cells must be removed from suspension. To facilitate this, suspensions were passed through a $40-\mu \mathrm{m}$ cell strainer to yield a homogenous population of single cells. A $100 \mu \mathrm{L}$ aliquot of the 'single-cell' suspension was placed in each well and spheroid formation was observed at $24 \mathrm{~h}$ and $48 \mathrm{~h}$. Cells were grown in their normal growth media using specialized concave microsphere plates (Corning, Model \#4515).

Cell Viability Measurements in 2-D cultures - MTT assay: MTT (3-(4,5dimethylthiazol-2-yl)-2,5-diphenyltetrazolium bromide) stock solutions were prepared by adding sterile PBS to a final concentration of $12.5 \mathrm{mM}$ MTT. Stock MTT was diluted in-well by the addition of $10 \mu \mathrm{L}$ of MTT stock to each well (1.1 mM final concentration). Plates were returned to the incubator for 4 hours. After incubation, $50 \mu \mathrm{L}$ of DMSO was added to each well to solubilize MTT crystals, and the plates were returned to the incubator for $10 \mathrm{~min}$. Absorbance was measured using a BioTek plate reader at $540 \mathrm{~nm}$.

Cell Viability Measurements in 3-D Spheroids: Only the AsPC-1 cells were utilized in this study due to the improved spheroid formation in the tumor cells compared to HPNE cells. Viability measurements were obtained using the CellTiter-Glo ${ }^{\circledR}-3 \mathrm{D}$ assay kit (Promega) as described in the manufacturer's guidelines and protocol. Following exposure to $\mathrm{NiCl}_{2}$ for $48 \mathrm{~h}$, assays were performed following the manufacturer protocol. Incubation was carried out at room temperature $\left(22^{\circ} \mathrm{C}\right)$ for 25 minutes, and the resulting ATP-related luminescence was measured at $590 \mathrm{~nm}$ using a BioTek plate reader.

Statistical Analysis: All data were analyzed using the non-normalized data using a one-way ANOVA, followed by Dunnett's-test for posthoc comparisons of treatment groups to control. LC50 values were analyzed by a two-tail t-test. All analyses and graphics were generated using GraphPad Prism (v8.4.3; GraphPad, San Diego, CA). Data are expressed as mean \pm SEM of ( $n=3-8)$. Alpha-level significance was set at $\alpha<0.05$. 


\section{Results}

3-D Spheroid Culture Growth: Both HPNE control cells and AsPC-1 tumor cells were grown in the specialized concave culture plates designed specifically for spheroid development (Figure 1). It was clear from the images and dilutions at both $24 \mathrm{~h}$ and $48 \mathrm{~h}$ incubation times that the AsPC-1 tumor cells formed spheroids with greater definition than HPNE cells. At the maximum $\left(10^{4}\right.$ cells/well; 100\%) concentration, a clearly defined spheroid was evident after $24 \mathrm{~h}$ in the AsPC-1 group. HPNE cells didn't form a conventional spheroid but instead formed a dense, asymmetrical 'clump.' Further examining cell dilutions, 50\% (5,000 cells/well), 25\% (2,500 cells/well), 12.5\% (1,250 cells/well) and $6.25 \%$ (625 cells/well) demonstrated that the AsPC-1 group formed spheroids even at the lowest concentration of cells, but the spheroid was less defined than with dilutions higher than $25 \%$.
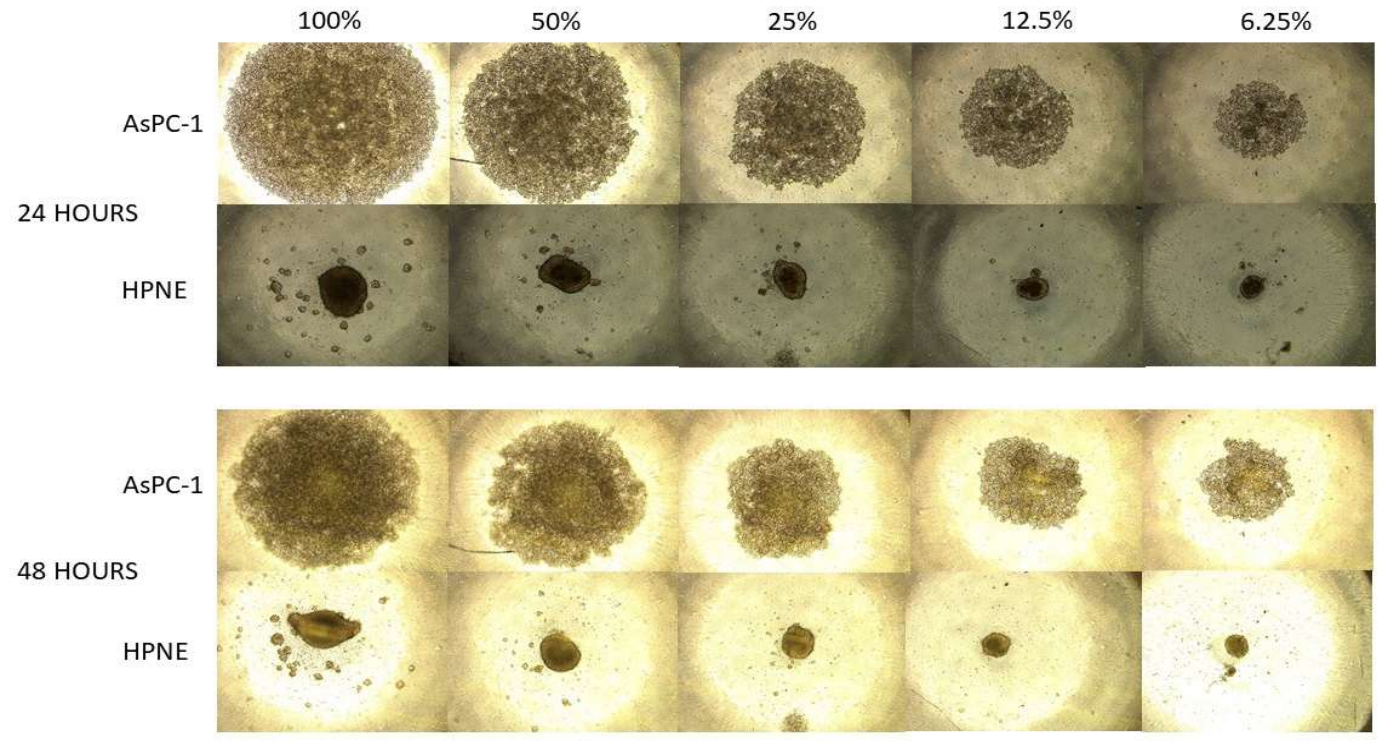

Figure 1. Culture dilution comparison of spheroid formation in pancreatic tumor (AsPC-1) and control (HPNE) cells. $100 \%$ suspension represents all cells from a $25 \mathrm{~cm}^{2}$ flask $\left(\sim 10^{6}\right.$ cells $\left./ \mathrm{mL}\right)$, the entire cell suspension was added to $10 \mathrm{~mL}$ of growth media prior to passage through a $40-\mu \mathrm{m}$ cell strainer to achieve single cell suspensions and facilitate normal spheroid development. Plates were returned to the incubator $\left(37^{\circ} \mathrm{C} / 5 \% \mathrm{CO}_{2}\right)$ for 24 and 48 hours.

Slika 1. Poređenje formiranja sferoida u tumorskim ćelijama pankreasa (AsPC-1) i kontrolnim (HPNE) ćelijama. 100\% suspenzija predstavlja sve ćelije iz suda zapremine $25 \mathrm{~cm}^{2}\left(\sim 10^{6}\right.$ ćelija / $\left.\mathrm{ml}\right)$, celokupna ćelijska suspenzija je dodata $\mathrm{u}$ $10 \mathrm{ml}$ medija za rast pre prolaska kroz filter od $40 \mu \mathrm{m}$, a da bi se postigle suspenzije pojedinačnih ćelija i olakšao normalan razvoj sferoida. Ploče su vraćene u inkubator $\left(37^{\circ} \mathrm{C} / 5 \% \mathrm{CO}_{2}\right)$ tokom 24 i 48 sati. 
Determination of $L C_{50}$ values for $C d$ and Ni: Incubating HPNE and AsPC-1 cells with increasing concentrations of $\mathrm{CdCl}_{2}(100 \mathrm{nM}-10 \mathrm{mM})$ resulted in reduced viability at the higher concentrations (Figure 2). Using the Least Squares Fit model, nonlinear regression analysis resulted in a converging fit for HPNE $\left(R^{2}=0.9814\right)$ and AsPC-1 $\left(R^{2}\right.$ $=0.9496)$ cells and provided $\mathrm{LC}_{50}$ for each run. To determine if 'within group' variance contributes to the 'between-group' differences, the D'Agostino-Pearson $(K 2)$ test was utilized, and both HPNE $(K 2=0.2595)$ and AsPC-1 cells $(K 2=0.4752)$ passed the normality test. Comparing the $\mathrm{LC}_{50}$ values (Figure 2, inset) revealed HPNE cells exhibited a significantly $(\mathrm{p}=0.0016)$ higher $\mathrm{LC}_{50}$ value $(69.9 \pm 9.1 \mu \mathrm{M})$ compared to AsPC-1 cells $(29.2 \pm 2.7 \mu \mathrm{M})$.

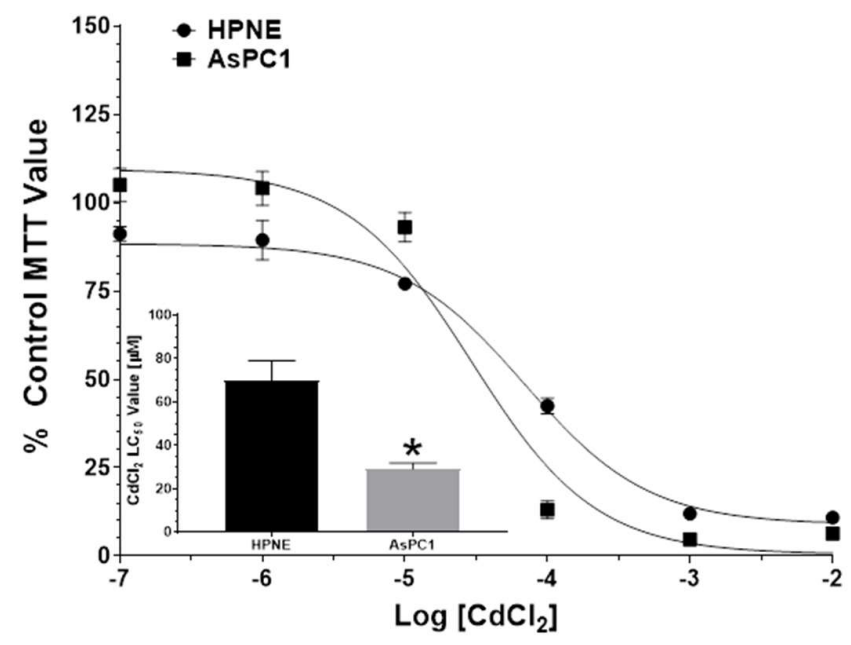

Figure 2. Reduction in cell viability following exposure to increasing cadmium concentrations for 48 hours. HPNE and AsPC1 cells were incubated with six concentrations $(100 \mathrm{nM}-10 \mathrm{mM})$ cadmium chloride were incubated with HPNE or AsPC-1 cells, and the MTT assay was used to determine cell viability. Data are expressed as the mean \pm SEM of six $(n=6)$ experiments performed in duplicate and were analyzed using GraphPad Prism (v.8.4.3) nonlinear regression to determine individual $\mathbf{L C}_{50}$ values. $\mathrm{LC}_{50}$ data is represented in the insert and is expressed as the mean $\pm \mathrm{SEM}$. * represents significantly $(\mathrm{P}=\mathbf{0 . 0 0 1 6})$ different from HPNE cell values.

Slika 2. Smanjenje ćelijske vijabilnosti nakon izloženosti rastućim koncentracijama kadmijuma tokom 48 sati. HPNE ili AsPC-1 ćelijske kulture inkubirane su sa šest rastućih koncentracija (100nM - 10mM) kadmijum hlorida. MTT esej je korišćen za utvrđivanje vijabilnosti ćelija. Podaci su izraženi kao srednja vrednost \pm standardna greška šest eksperimenata izvršenih u duplikatima i analizirani su pomoću GraphPad Prism (v. 8.4.3) upotrebom nelinearne regresije za utvrđivanje pojedinačnih LC $_{50}$ vrednosti. Podaci o LC So $_{5}$ vrednostima su predstavljeni u umetku i izraženi su kao srednja vrednost \pm standardna greška. * predstavlja značajnu razliku ( $P=0.0016)$ u odnosu na vrednosti dobijene u HPNE ćelijama. 
HPNE and AsPC-1 cells with increasing concentrations of $\mathrm{NiCl}_{2}(100 \mathrm{nM}-10 \mathrm{mM}$; Figure 3, top panel) or $\mathrm{Ni}-(\mathrm{Ac})_{2}(100 \mathrm{nM}-10 \mathrm{mM}$; Figure 3, bottom panel). Like measuring $\mathrm{CdCl}_{2}$ response, nonlinear regression analysis using the Least Squares Fit model following $\mathrm{NiCl}_{2}$ exposure resulted in a converging fit for $\operatorname{HPNE}\left(R^{2}=0.9780\right)$ and AsPC-1 $\left(R^{2}=0.8886\right)$ cells and provided $\mathrm{LC}_{50}$ for each run. Variance within the $\mathrm{NiCl}_{2}$ group resulted in a significant D'Agostino-Pearson (K2) test in AsPC-1 cells $(K 2=$ $19.52)$, but not in the HPNE $(K 2=0.9983)$ group, which passed the normality test. Variances that fail the test for normality suggest that the data does not follow conventional Gaussian distribution. Comparing the $\mathrm{LC}_{50}$ values (Figure 3, top inset), HPNE cells exhibited a slightly higher, but nonsignificant, $\mathrm{LC}_{50}$ value $(1.15 \pm 0.11 \mathrm{mM})$ compared to AsPC-1 cells $(0.86 \pm 0.13 \mathrm{mM})$. Using the same analysis model for the $\mathrm{Ni}-(\mathrm{Ac})_{2}$ exposure group, both curves converged for HPNE $\left(R^{2}=0.9090\right)$, and AsPC-1 $\left(R^{2}=0.8720\right)$ cells, and each assay provided $\mathrm{LC}_{50}$ values. Variance within data from both cell lines resulted in a significant D'Agostino-Pearson $(K 2)$ test in both AsPC-1 cells $(K 2=15.54)$ and HPNE $(K 2=9.963)$ groups. Comparing the $\mathrm{LC}_{50}$ values (Figure 3, bottom inset), the $\mathrm{LC}_{50}$ values for the HPNE group $(0.68 \pm 0.13 \mathrm{mM})$ were not different compared to the AsPC-1 group $(0.53 \pm 0.03 \mathrm{mM})$. Generally, the $\mathrm{LC}_{50}$ values for the Ni compounds were about 10 - to 20 -fold higher than for $\mathrm{Cd}$, ranging from $69 \mu \mathrm{M}$ to $1.15 \mathrm{mM}$ in HPNE cells and from $29 \mu \mathrm{M}$ to $860 \mu \mathrm{M}$ in AsPC-1 cells.

$\mathrm{Ni}$-mediated changes in viability in AsPC-1 spheroid cultures: AsPC-1 cells were grown in spheroid culture as described in the methods. Plates were returned to the incubator for $24 \mathrm{~h}$ at which time the media was removed, assay media added, and the photomicrograph $(10 \mathrm{x})$ taken, representing the $0 \mathrm{~h}$ time point (Figure 4, left panel). Note the yellow circle on each panel encompassing the spheroid. The same circle is positioned on the right side of the image, $48 \mathrm{~h}$ after exposure to $50 \mu \mathrm{M} \mathrm{NiCl}_{2}$ or $\mathrm{Ni}-(\mathrm{Ac})_{2}$. We observed that after $48 \mathrm{~h}$ of exposure, there did not appear to be a reduction in cell number, but the spheroids lost their organized structure, starting on the outer layers of the spheroid. Measuring the cell viability in the spheroid, we observed no noticeable reduction in viability or ATP release following one-way ANOVA analysis examining the effect of treatment (Figure 4, right panel). The rationale for using $50 \mu \mathrm{M} \mathrm{NiCl}_{2}$ or Ni-(Ac) 2 was to examine the low concentration effects. By modifying the equation for fractional occupancy (eq. 1) for $\mathrm{LC}_{50}$, we can derive an estimate of the lethality based on the metal concentration and its $\mathrm{LC}_{50}$ value.

$$
\% \text { Lethality }=\frac{[\text { metal }]}{[\text { metal }]+L C 50}
$$

Using this modified equation, we can estimate the cell lethality for $50 \mu \mathrm{M} \mathrm{NiCl}_{2}$ to be $5.5 \%$, and for $\mathrm{Ni}-(\mathrm{Ac})_{2}$, the lethality is $8.6 \%$. In both instances, low lethality would be within the error of the viability assay. Although viability was low, exposure to $\mathrm{Ni}$ appeared to disrupt the formation of the spheroid. 

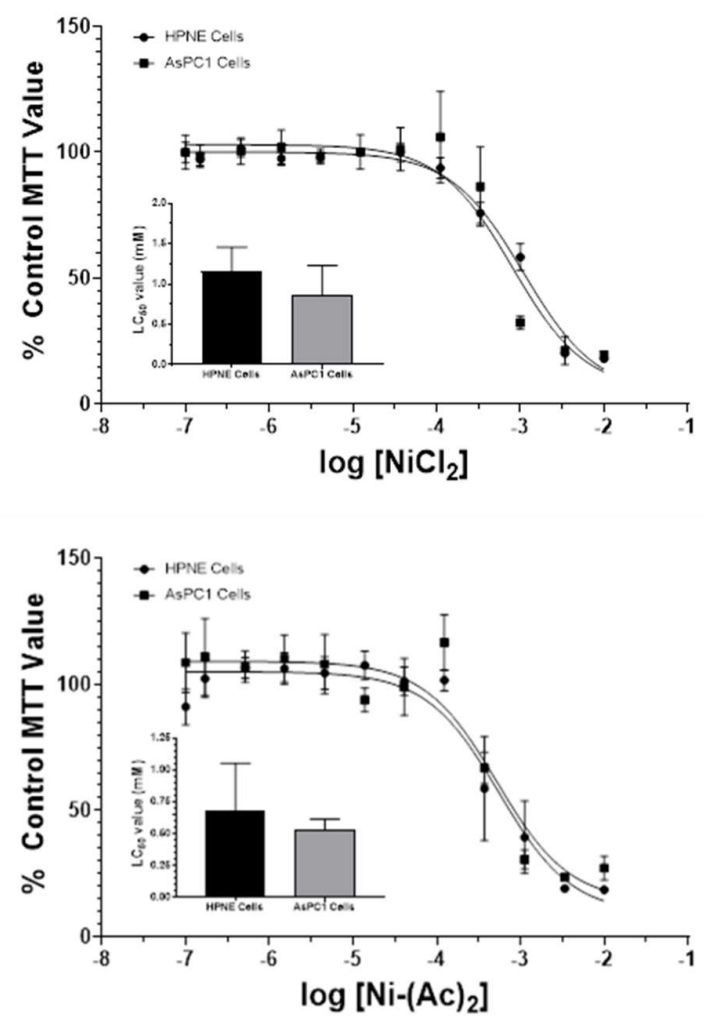

Figure 3. Minimal reduction in cell viability following exposure to increasing nickel chloride (top panel) or acetate (bottom panel) after 48 hours. Twelve concentrations $(100 \mathrm{nM}-10 \mathrm{mM})$ of nickel chloride or nickel acetate were incubated with HPNE or AsPC-1 cells, and the MTT assay was used to determine cell viability following exposure for 48 hours. Data are expressed as the mean \pm SEM of eight $(n=8)$ experiments performed in duplicate and analyzed using GraphPad Prism (v.8.4.3) nonlinear regression to determine individual $\mathrm{LC}_{50}$ values. $\mathrm{LC}_{50}$ data is represented in the insert and is expressed as the mean \pm SEM.

Slika 3. Minimalno smanjenje održivosti ćelija nakon izlaganja rastućim koncentracijama nikl-hlorida (gornja ploča) ili acetata (donja ploča) nakon 48 sati. HPNE ili AsPC-1 ćelijske kulture inkubirane su sa dvanaest rastućih koncentracija (100 nM - $10 \mathrm{mM})$ nikl hlorida ili nikl acetata. MTT test je korišćen za određivanje vijabilnosti ćelija nakon izlaganja tokom 48 sati. Podaci su izraženi kao srednja vrednost \pm standardna greška osam eksperimenata izvedenih u duplikatu i analizirani su pomoću GraphPad Prism (v. 8.4.3) upotrebom nelinearne regresije za utvrđivanje pojedinačnih $\mathrm{LC}_{50}$ vrednosti. Podaci o $\mathrm{LC}_{50}$ vrednostima su predstavljeni u umetku i izraženi su kao srednja vrednost \pm standardna greška. 

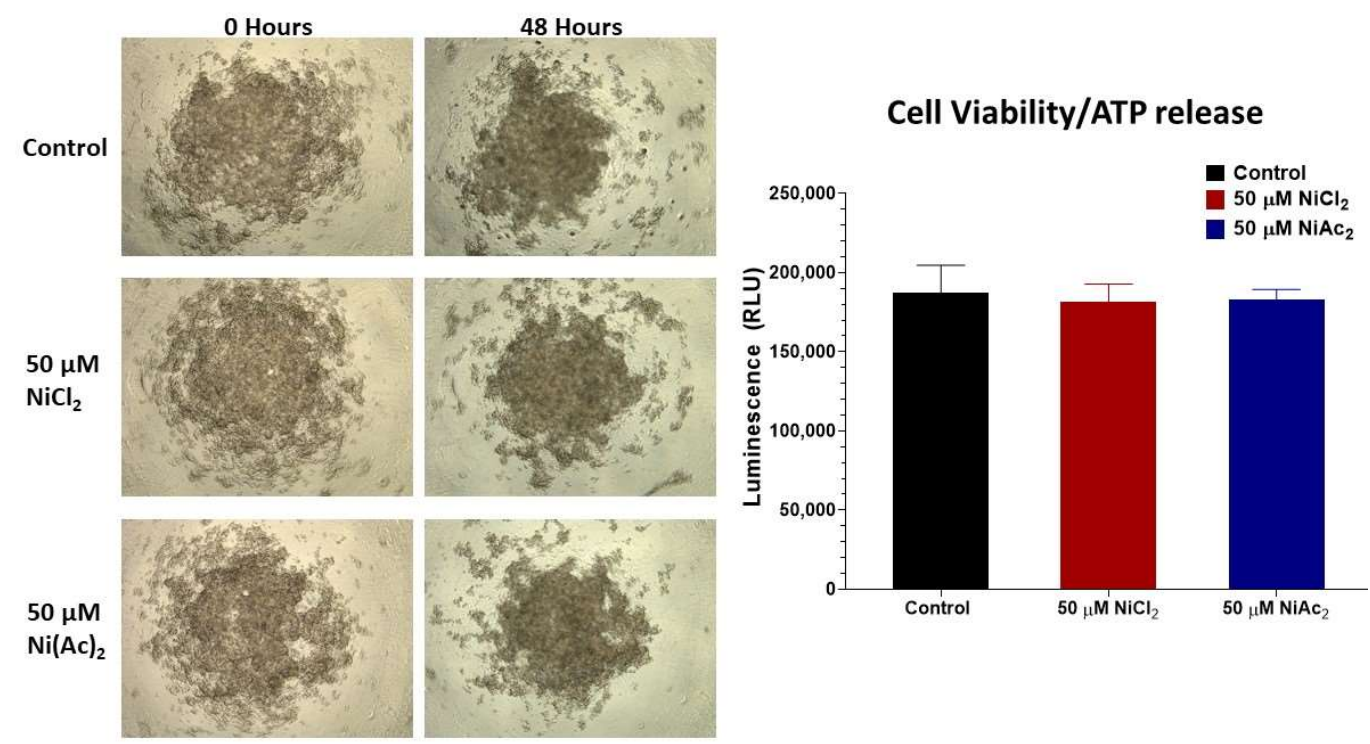

Figure 4. Analysis of nickel cytotoxicity in AsPC-1 3-D cultures. Cells were grown and plated in the Corning 96-well plates designed for promoting spheroid formation as described in the 'Methods'. Cells began spheroid formation within $24 \mathrm{~h}$, and the initial photograph (Leica inverted scope, $5 x$ objective) was taken. Cells were exposed to media (control), $50 \mu \mathrm{M} \mathrm{NiCl} 2$, or $50 \mu \mathrm{M}$ Ni-acetate for $48 \mathrm{~h}$. Another photomicrograph was taken, and cell viability was determined using Promega's CellTiter-Glo assay. Luminescence was measured at 590nm (determined as optimum signal/noise). Data are expressed as the means \pm SEM of 4 assays performed in duplicate $(n=4)$.

Slika 4. Analiza citotoksičnosti nikla u AsPC-1 3-D ćelijskim kulturama. Ćelije su uzgajane u Corning pločama sa 96 mesta dizajniranim za promovisanje sferoidnih formacija kao što je opisano u delu Metode. Ćelije su započele sferoidno formiranje u roku od $24 \mathrm{~h}$ i snimljena je inicijalna fotografija. Ćelije su bile izložene medijima: kontrolnom, $50 \mu \mathrm{M}$ nikl-hlorida ili $50 \mu \mathrm{M}$ nikl-acetata tokom 48h. Snimljen je još jedan fotomikrograf, a vijabilnost ćelija određena je korišćenjem Promega's CellTiter-Glo eseja. Luminescencija je izmerena na 590nm (optimalni odnos signal/buka). Podaci su izraženi kao srednja vrednost \pm standardna greška 4 eseja izvršena u duplikatima. 


\section{Discussion}

Our previous studies have established a body of evidence that strongly suggests that $\mathrm{Cd}$ is toxic in the pancreas and may lead to the development of pancreatic cancer, and other physiological dysfunctions such as insulin dysregulation and thyroid dysfunction (44-47). Ni and Ni-containing compounds have not been studied to the same extent as $\mathrm{Cd}$. As a result, the primary aim of this study was to begin an investigation into Nimediated toxicity in the pancreas. Also, we initiated studies to compare the actions of toxicants in 2-D versus 3-D cell culture. There are subtle differences between toxicant responses in the two systems $(35,36)$. In particular, the pancreas has become an organ system critical for the development of 3-D model systems to be used in cancer studies (42). To date, few studies have utilized 3-D cultures in the study of PC, and none have examined Ni's effects following short-term exposure.

Using $\mathrm{Cd}$ toxicity as an internal assay control to assess Ni-mediated toxicity was done to validate our assay conditions. The determination of $\mathrm{LC}_{50}$ values for $\mathrm{Cd}$ was similar to what we have previously reported (47). Contrary to our findings with $\mathrm{Cd}$, the toxicity of $\mathrm{Ni}$ was minimal in the initial 2-D studies. Our $\mathrm{LC}_{50}$ values were 10 -20-fold higher than for $\mathrm{Cd}(>500 \mu \mathrm{M})$. The present studies lay the foundation for a future examination into the cellular effects of Ni-mediated toxicity.

On the surface, the relatively low lethality associated with either $\mathrm{NiCl}_{2}$ or $\mathrm{Ni}-(\mathrm{Ac})_{2}$ exposure for $48 \mathrm{~h}$ would suggest a generalized lack of toxicity associated with $\mathrm{Ni}$. These findings are supported by current literature describing Ni-mediated effects in a variety of model systems. In rodent $\beta$-cells, exposure to $\mathrm{NiCl}_{2}$ for $24 \mathrm{~h}$ did not elicit a significant reduction in viability until the test concentration exceeded $1 \mathrm{mM}$ (15). In mouse and human cell lines, $\mathrm{NiCl}_{2}$ exposure elicits an interesting profile of toxicity. In mouse cells, lower concentrations of $\mathrm{Ni}(100-200 \mu \mathrm{M})$ increased viability compared to control values, but at $600-800 \mu \mathrm{M}$, there was a nearly $50 \%$ reduction in viability (48). In human HepG2 cells, increasing $\mathrm{Ni}$ concentration, resulted in decreasing viability, with a $50 \%$ reduction at 400-600 $\mu \mathrm{M}$ (48). In human lymphocytes, significant reductions in viability were not observed until a concentration of $3 \mathrm{mM}$ was exceeded (18). The viability reports in the literature support our findings of $\mathrm{LC}_{50}$ values of $>500 \mu \mathrm{M}$ dependent on the cell line and the chemical form of $\mathrm{Ni}$ (organic or inorganic). Although not overtly toxic, further studies will be needed to investigate long-term exposure to $\mathrm{Ni}$.

One of the mechanisms of Ni-induced toxicity is the promotion of oxidative stress. When the current information is examined, it is evident that Ni's ability to induce free radical generation is about as potent as its lethality. In vivo models using injections of moderately high $\mathrm{Ni}$ doses resulted in increased expression/activity of various biomarkers. These biomarkers are associated with oxidative stress such as alkaline phosphatase, aspartate transaminase, oxidized lipids, malondialdehyde, or glutathione reduction $(20,49,50)$. A study by Chen et al. (18) generation of free radicals following $\mathrm{NiCl}_{2}$ administration showed that dichlorofluorescein fluorescence was not elevated until a concentration of $1 \mathrm{mM}$ was used. The use of high concentrations suggests $\mathrm{Ni}$ is a weak 
promoter of oxidative stress. Exposure duration was only $1 \mathrm{~h}$, which for an in vitro assay would be sufficient for significant radical generation, only yielded a 3-fold increase in oxidative stress over baseline (18). Even if $\mathrm{Ni}$ is a weak free radical generator, the in vivo studies leave open the possibility that a second pathway is involved. Ni administration may work through multiple pathways to increase oxidative stress.

Although $\mathrm{Ni}$ is considered a carcinogen, it has been shown to exhibit an inverse correlation between Ni content and the incidence of PC $(31,32)$. One report demonstrated a positive correlation between $\mathrm{Ni}$ content and PC involving KRAS mutations (51). There is a mounting body of evidence that supports Ni involvement in an array of pancreasrelated dysfunction. Application of $\mathrm{Cd}$ to $\beta$-cells elicits responses mediated by the L-type (long-lasting) calcium channels, whereas Ni works through the transient T-type calcium channels (52). When $\mathrm{Ni}$ is applied to $\beta$-cells, there was no response in calcium flux or insulin release suggesting a lack of T-type channels on $\beta$-cells. Yet, there is a mechanism for $\mathrm{Ni}$-induced damage in the pancreas. Parental exposure to $\mathrm{NiCl}_{2}$ results in an increase in oxidative stress markers in the pancreas (14). Ni itself appears to be a 'hyperglycemic' metal, a metal that promotes blood glucose elevation, either by reducing insulin release, blocking insulin action, or promoting glycogen breakdown/de novo glucose synthesis. The in vivo result of $\mathrm{Ni}$ exposure is hyperglycemia resembling diabetes and may involve other mediators $(21,53,54)$.

Collectively, these studies provide the foundation and the initial set of data that we can build from moving forward in our study of Ni toxicity and its involvement in PC development. The use of 3-D cultures is critical for furthering our understanding of metalor Ni-induced toxicity and PC development. The tumor cells tend to form very distinct and orderly spheroids. In the concave well model, control HPNE cells tended to form more of a dense cluster that doesn't resemble the archetypical spheroid. A different model system may be needed, with the use of Matrigel ${ }^{\circledR}$ or magnetic microbeads as potential options that would by-pass the need for the cells to initiate their spheroid formation. Initially, it appears that our $\mathrm{LC}_{50}$ values were low, but when compared to the literature, $\mathrm{Ni}$ is not a highly lethal metal. Concentrations $>500 \mu \mathrm{M}$ are needed to elicit an increase in free radical formation or cell death. Interestingly, it appears that Ni may be involved with other metals or toxicants, and the relationship between the different toxicants will direct the toxic outcome. The theory of chemical mixture toxicity needs to be explored further. Future studies are already underway characterizing cellular changes involving apoptotic pathways following $\mathrm{Ni}$ exposure. Another interesting avenue to pursue is $\mathrm{Ni}$ exposure resulting in epigenetic changes (55-58). As technology continues to develop and advance, we will continue to advance our understanding of Ni-mediated toxicity and $\mathrm{Ni}$ involvement in PC development.

\section{Acknowledgements}

Oklahoma IDeA Network of Biomedical Research Excellence (OK-INBRE; P20GM103447; DRW), through the National Institutes of Health and the OSU-CHS 
Office of the Vice President for Research Seed Grant (\#1-54333; DRW). The authors would also like to thank Liming Fan for technical assistance in the performance of the Ni $\mathrm{LC}_{50}$ analysis.

\section{References}

1. Das KK, Reddy RC, Bagoji IB, Das S, Bagali S, Mullur L, et al. Primary concept of nickel toxicity - An overview. J Basic Clin Physiol Pharmacol. 2019;30(2):141-52.

2. Genchi G, Carocci A, Lauria G, Sinicropi MS, Catalano A. Nickel: Human health and environmental toxicology. Int J Environ Res Public Health. 2020;17(3):679.

3. Rehman K, Fatima F, Waheed I, Akash MSH. Prevalence of exposure of heavy metals and their impact on health consequences. J Cell Biochem. 2018 Jan;119(1):157-84.

4. Romero-Estévez D, Yánez-Jácome GS, Simbaña-Farinango K, Navarrete H. Distribution, Contents, and Health Risk Assessment of Cadmium, Lead, and Nickel in Bananas Produced in Ecuador. Foods (Basel, Switzerland). 2019 Aug;8(8).

5. Marzec Z, Koch W, Marzec A, Żukiewicz-Sobczak W. Dietary exposure to cadmium, lead and nickel among students from south-east Poland. Ann Agric Environ Med. 2014;21(4):825-8.

6. Hess CA, Olmedo P, Navas-Acien A, Goessler W, Cohen JE, Rule AM. E-cigarettes as a source of toxic and potentially carcinogenic metals. Environ Res. 2017 Jan;152:221-5.

7. Gray N, Halstead M, Gonzalez-Jimenez N, Valentin-Blasini L, Watson C, Pappas RS. Analysis of Toxic Metals in Liquid from Electronic Cigarettes. Int J Environ Res Public Health. 2019 Nov;16(22).

8. Pesch B, Kendzia B, Pohlabeln H, Ahrens W, Wichmann H-E, Siemiatycki J, et al. Exposure to Welding Fumes, Hexavalent Chromium, or Nickel and Risk of Lung Cancer. Am J Epidemiol [Internet]. 2019 Nov 1;188(11):1984-93. Available from: https://doi.org/10.1093/aje/kwz187

9. Yang SY, Lin JM, Lin WY, Chang CW. Cancer risk assessment for occupational exposure to chromium and nickel in welding fumes from pipeline construction, pressure container manufacturing, and shipyard building in Taiwan. J Occup Health. 2018;60(6):515-24.

10. Nduka JK, Kelle HI, Amuka JO. Health risk assessment of cadmium, chromium and nickel from car paint dust from used automobiles at auto-panel workshops in Nigeria. Toxicol Reports. 2019;6:44956.

11. Sciannameo V, Ricceri F, Soldati S, Scarnato C, Gerosa A, Giacomozzi G, et al. Cancer mortality and exposure to nickel and chromium compounds in a cohort of Italian electroplaters. Am J Ind Med. 2019 Feb;62(2):99-110.

12. Hsieh S-H, Chiu T-P, Huang W-S, Chen T-C, Yeh Y-L. Cadmium (Cd) and Nickel (Ni) Distribution on Size-Fractioned Soil Humic Substance (SHS). Int J Environ Res Public Health. 2019 Sep;16(18).

13. Rezuke WN, Knight JA, Sunderman FWJ. Reference values for nickel concentrations in human tissues and bile. Am J Ind Med. 2012;30(3):189-224. 
14. Novelli EL, Sforcin JM, Rodrigues NL, Ribas BO. Pancreas damage and intratracheal $\mathrm{NiCl} 2$ administration. Effects of nickel chloride. Bol Estud Med Biol. 1990;38(3-4):54-8.

15. Wu H-C, Yang C-Y, Hung D-Z, Su C-C, Chen K-L, Yen C-C, et al. Nickel(II) induced JNK activation-regulated mitochondria-dependent apoptotic pathway leading to cultured rat pancreatic beta-cell death. Toxicology. 2011 Nov;289(2-3):103-11.

16. Rana SVS. Perspectives in endocrine toxicity of heavy metals--a review. Biol Trace Elem Res. 2014 Jul;160(1):1-14.

17. Aquino NB, Sevigny MB, Sabangan J, Louie MC. Breast Cancer : Metalloestrogens or Not? J Env Sci Heal. 2013;30(3):189-224.

18. Chen CY, Wang YF, Lin YH, Yen SF. Nickel-induced oxidative stress and effect of antioxidants in human lymphocytes. Arch Toxicol. 2003;77(3):123-30.

19. Chang W-H, Lee C-C, Yen Y-H, Chen H-L. Oxidative damage in patients with benign prostatic hyperplasia and prostate cancer co-exposed to phthalates and to trace elements. Environ Int. 2018 Dec;121(Pt 2):1179-84.

20. Das KK, Das SN, Dhundasi SA. Nickel, its adverse health effects \& oxidative stress. Indian J Med Res. 2008 Oct;128(4):412-25.

21. Chen YW, Yang CY, Huang CF, Hung DZ, Leung YM, Liu SH. Heavy metals, islet function and diabetes development. Islets. 2009;1(3):169-76.

22. Hariharan D, Saied A, Kocher HM. Analysis of mortality rates for pancreatic cancer across the world. HPB. 2008;10(1):58-62.

23. American Cancer Society. Cancer Facts \& Figures 2013. American Cancer Society. 2013.

24. Barone E, Corrado A, Gemignani F, Landi S. Environmental risk factors for pancreatic cancer: an update. Arch Toxicol. 2016;90(11):2617-42.

25. TSDR. Toxicological Profile for Cadmium. Agency Toxic Subst Dis Regist Public Heal Serv US Dep Heal Hum Serv. 2012;(September):1-487.

26. Inaba T, Kobayashi E, Suwazono Y, Uetani M, Oishi M, Nakagawa H, et al. Estimation of cumulative cadmium intake causing Itai-itai disease. Toxicol Lett. 2005;159(2):192-201.

27. Vuori E, Huunan Seppala A, Kilpio JO. Biologically active metals in human tissues. I. The effect of age and sex on the concentration of copper in aorta, heart, kidney, liver, lung, pancreas and skeletal muscle. Scand J Work Environ Heal. 1978;4(2):167-75.

28. Gerin M, Siemiatycki J, Richardson L, Pellerin J, Lakhani R, Dewar R. Nickel and cancer associations from a multicancer occupation exposure case-referent study: preliminary findings. IARC Sci Publ. 1984;(53):105-15.

29. Chen QY, DesMarais T, Costa M. Metals and Mechanisms of Carcinogenesis. Annu Rev Pharmacol Toxicol. 2019;59(3):537-54.

30. Zhu Y, Costa M. Metals and molecular carcinogenesis. Carcinogenesis [Internet]. 2020 Jul 17;41(9):1161-72. Available from: https://doi.org/10.1093/carcin/bgaa076

31. Amaral AFSAFS, Porta M, Silverman DT, Milne RL, Kogevinas M, Rothman N, et al. Pancreatic cancer risk and levels of trace elements. Gut [Internet]. 2012 Nov;61(11):1583-8. Available from: http://gut.bmj.com/lookup/doi/10.1136/gutjnl-2011-301086 
32. Kashiwagi M, Akimoto H, Goto J, Aoki T. Analysis of zinc and other elements in rat pancreas, with studies in acute pancreatitis. J Gastroenterol. 1995 Feb;30(1):84-9.

33. Carrigan PE, Hentz JG, Gordon G, Morgan JL, Raimondo M, Anbar AD, et al. Distinctive heavy metal composition of pancreatic juice in patients with pancreatic carcinoma. Cancer Epidemiol Biomarkers Prev. 2007 Dec;16(12):2656-63.

34. Yeon S-E, No DY, Lee S-H, Nam SW, Oh I-H, Lee J, et al. Application of Concave Microwells to Pancreatic Tumor Spheroids Enabling Anticancer Drug Evaluation in a Clinically Relevant Drug Resistance Model. PLoS One [Internet]. 2013 [cited 2018 Jan 3];8(9):e73345. Available from: http://journals.plos.org/plosone/article/file?id=10.1371/journal.pone.0073345\&type=printable

35. Sant S, Johnston PA. The production of 3D tumor spheroids for cancer drug discovery. Drug Discov Today Technol [Internet]. 2017;23:27-36. Available from: http://dx.doi.org/10.1016/j.ddtec.2017.03.002

36. Nath S, Devi GR. Three-dimensional culture systems in cancer research: Focus on tumor spheroid model. Pharmacol Ther [Internet]. 2016;163:94-108. Available from:

http://dx.doi.org/10.1016/j.pharmthera.2016.03.013

37. Costa EC, Moreira AF, de Melo-Diogo D, Gaspar VM, Carvalho MP, Correia IJ. 3D tumor spheroids: an overview on the tools and techniques used for their analysis. Biotechnol Adv [Internet]. 2016;34(8):1427-41. Available from: http://dx.doi.org/10.1016/j.biotechadv.2016.11.002

38. Rodrigues T, Kundu B, Silva-Correia J, Kundu SC, Oliveira JM, Reis RL, et al. Emerging tumor spheroids technologies for 3D in vitro cancer modeling. Pharmacol Ther [Internet].

2018;184(October 2017):201-11. Available from: https://doi.org/10.1016/j.pharmthera.2017.10.018

39. Thoma CR, Zimmermann M, Agarkova I, Kelm JM, Krek W. 3D cell culture systems modeling tumor growth determinants in cancer target discovery. Adv Drug Deliv Rev [Internet]. 2014;6970:29-41. Available from: http://dx.doi.org/10.1016/j.addr.2014.03.001

40. Weigelt B, Ghajar CM, Bissell MJ. The need for complex 3D culture models to unravel novel pathways and identify accurate biomarkers in breast cancer. Adv Drug Deliv Rev [Internet]. 2014;69-70:42-51. Available from: http://dx.doi.org/10.1016/j.addr.2014.01.001

41. Ware MJ, Colbert K, Keshishian V, Ho J, Corr SJ, Curley SA, et al. Generation of Homogenous Three-Dimensional Pancreatic Cancer Cell Spheroids Using an Improved Hanging Drop Technique. Tissue Eng Part C Methods [Internet]. 2016;22(4):312-21. Available from: http://online.liebertpub.com/doi/10.1089/ten.tec.2015.0280

42. Longati P, Jia X, Eimer J, Wagman A, Witt MR, Rehnmark S, et al. 3D pancreatic carcinoma spheroids induce a matrix-rich, chemoresistant phenotype offering a better model for drug testing. BMC Cancer. 2013;13:1-13.

43. Lee KM, Nguyen C, Ulrich AB, Pour PM, Ouellette MM. Immortalization with telomerase of the Nestin-positive cells of the human pancreas. Biochem Biophys Res Commun. 2003;301(4):103844. 
44. Buha A, Matovic V, Antonijevic B, Bulat Z, Curcic M, Renieri EA, et al. Overview of cadmium thyroid disrupting effects and mechanisms. Int J Mol Sci. 2018;19(5):1501.

45. Buha A, Wallace D, Matovic V, Schweitzer A, Oluic B, Micic D, et al. Cadmium Exposure as a Putative Risk Factor for the Development of Pancreatic Cancer: Three Different Lines of Evidence. Biomed Res Int. 2017;2017(Cd):1-8.

46. Djordjevic VR, Wallace DR, Schweitzer A, Boricic N, Knezevic D, Matic S, et al. Environmental cadmium exposure and pancreatic cancer: Evidence from case control, animal and in vitro studies. Environ Int [Internet]. 2019;128:353-61. Available from: https://linkinghub.elsevier.com/retrieve/pii/S0160412019301291

47. Wallace D, Spandidos D, Tsatsakis A, Schweitzer A, Djordjevic V, Djordjevic A. Potential interaction of cadmium chloride with pancreatic mitochondria: Implications for pancreatic cancer. Int J Mol Med. 2019;44:145-56.

48. Terpiłowska S, Siwicka-Gieroba D, Krzysztof Siwicki A. Cell viability in normal fibroblasts and liver cancer cells after treatment with iron (III), nickel (II), and their mixture. J Vet Res. 2018;62(4):535-42.

49. Novelli EL, Rodrigues NL, Ribas BO, Estadual U. Superoxide radical and toxicity of environmental nickel exposure. Hum Exp Toxicol. 1994 Mar;14(3):248-51.

50. Šulinskiene J, Bernotiene R, Baranauskiene D, Naginiene R, Stanevičiene I, Kašauskas A, et al. Effect of Zinc on the Oxidative Stress Biomarkers in the Brain of Nickel-Treated Mice. Oxid Med Cell Longev. 2019;2019:ID 8549727.

51. Gómez-Tomás Á, Pumarega J, Alguacil J, Amaral AFS, Malats N, Pallarès N, et al. Concentrations of trace elements and KRAS mutations in pancreatic ductal adenocarcinoma. Environ Mol Mutagen. 2019 Oct;60(8):693-703.

52. Plasman PO, Hermann M, Herchuelz A, Lebrun P. Sensitivity to Cd2+ but resistance to Ni2+ of Ca2+ inflow into rat pancreatic islets. Am J Physiol. 1990 Mar;258(3 Pt 1):E529-533.

53. Wang X, Gao D, Zhang G, Zhang X, Li Q, Gao Q, et al. Exposure to multiple metals in early pregnancy and gestational diabetes mellitus: A prospective cohort study. Environ Int. 2020 Feb;135:105370.

54. Gupta S, Ahmad N, Husain MM, Srivastava RC. Involvement of nitric oxide in nickel-induced hyperglycemia in rats. Nitric Oxide. 2000 Apr;4(2):129-38.

55. Martinez-Zamudio R, Ha HC. Environmental epigenetics in metal exposure. Epigenetics. 2011 Jul;6(7):820-7.

56. Cameron KS, Buchner V, Tchounwou PB. Exploring the molecular mechanisms of nickel-induced genotoxicity and carcinogenicity: a literature review. Rev Environ Health. 2011;26(2):81-92.

57. Permenter MG, Lewis JA, Jackson DA. Exposure to nickel, chromium, or cadmium causes distinct changes in the gene expression patterns of a rat liver derived cell line. PLoS One. 2011;6(11):e27730.

58. Jordan A, Zhang X, Li J, Laulicht-Glick F, Sun H, Costa M. Nickel and cadmium-induced SLBP depletion: A potential pathway to metal mediated cellular transformation. PLoS One. 2017;12(3):e0173624. 


\title{
Toksičnost organskog i neogranskog nikla u ćelijskim kulturama pankreasa: poređenje sa kadmijumom
}

\author{
David R Wallace*1, Aleksandra Buha-Djordjević ${ }^{2}$, Alexander Benton ${ }^{3}$ \\ ${ }^{1}$ Oklahoma State University Center for Health Sciences, School of Biomedical Sciences \\ and Interdisciplinary Toxicology Program, 1111 West $17^{\text {th }}$ Street, Tulsa Oklahoma, \\ 74107-1898 United States \\ ${ }^{2}$ Univerzitet u Beogradu - Farmaceutski fakultet, Katedra za toksikologiju „Akademik \\ Danilo Soldatović”, Vojvode Stepe 450, 11221 Beograd, Srbija \\ ${ }^{3}$ Oklahoma State University, Department of Biochemistry and Molecular Biology, \\ Program in Biochemistry and Molecular Biology, Noble Research Center, Stillwater, \\ Oklahoma, 74078 United States
}

*Autor za korenspodenciju: David R Wallace, E-mail: david.wallace@okstate.edu

\section{Kratak sadržaj}

Uloga nikla, toksičnog metala, u nastanku karcinoma pankreasa još uvek nije u potpunosti ispitana. Cilj rada je da ispita toksičnost nikla (Ni) u 2-D i 3-D kulturi ćelija pankreasa, kako bi se utvrdila $\mathrm{LD}_{50}$ vrednost za organski i neorganski nikl u normalnim i tumorskim ćelijama. Ispitivanja su izvršena i sa kadmijumom (Cd), metalom čija je uloga u nastanku karcinoma pankreasa potvrđena $\mathrm{u}$ prethodnim istraživanjima, a u svrhu poređenja sa potencijalnom toksičnošću izazvanom Ni. Ćelije su bile tretirane sa 12 različitih koncentracija $\mathrm{NiCl}_{2}$ ili Ni-(Ac) tokom 48h (2-D), odnosno sa šest različitih koncentracija tokom 48 sati (3-D). Nijedan oblik Ni nije ispoljio toksičnost u 2-D ili 3-D kulturama, ali nakon 48h primećene su promene u sferoidnoj morfologiji. Nemogućnost Ni da smanji broj vijabilnih ćelija sugeriše mehanizam karcinogeneze različit od mehanizma koji ispoljava Cd. Ipak, da bi se uočile izmene u funkciji DNK ili izražavanju apoptotičkih proteina/procesa potrebno je duže vremena, pa su dalja istraživanja upravo fokusirana na ćelijske promene nakon produžene izloženosti nikla.

Ključne reči: nikl; kadmijum; citotoksičnost; toksični metali; karcinom 